\title{
Mercury Bio-Concentration by Puffballs (Lycoperdon perlatum) and Evaluation of Dietary Intake Risks
}

\author{
Jerzy Falandysz • Innocent C. Nnorom • \\ Grażyna Jarzyńska • Dominika Romińska • \\ Kamila Damps
}

Received: 7 May 2012/Accepted: 8 August 2012/Published online: 18 August 2012

(c) The Author(s) 2012. This article is published with open access at Springerlink.com

\begin{abstract}
In the present study, $\mathrm{Hg}$ bioconcentration by Puffball (Lycoperdon perlatum) mushroom was investigated. Total $\mathrm{Hg}$ content of fruiting bodies and topsoil $(0-10 \mathrm{~cm}$ layer) were determined by cold-vapour atomic absorption spectroscopy. For ten geographically distant sampling sites of Poland, $\mathrm{Hg}$ ranged from $0.91 \pm 0.28$ to $2.4 \pm 0.4$ (overall range $0.57-4.5$ ) $\mu \mathrm{g} / \mathrm{g}$ dry weight in the carpophores and $0.012 \pm 0.002$ to $0.063 \pm 0.024$ (overall range $0.0077-0.12) \mu \mathrm{g} / \mathrm{g} \mathrm{dw}$ in topsoil. The mean values of the bioconcentration factor ranged from $28 \pm 11$ to $110 \pm 36$ (range 9.6-280) indicating that L. perlatum effectively accumulates $\mathrm{Hg}$ and could be classified as a $\mathrm{Hg}$ accumulator. Total $\mathrm{Hg}$ content of $L$. perlatum to some degree seems to be determined both by degree of soil contamination and metal bioavailability to mycelium and also the rate of transfer and accumulation in fruiting bodies at the sites surveyed. Summarized and discussed are published data available on total $\mathrm{Hg}$ and methylmercury in L. perlatum.
\end{abstract}

Keywords Bioconcentration - Foods - Forest · Mushrooms · Soils · Wild foods

Mercury is a global pollutant and remains as one of the most hazardous compounds that contaminate foods and

J. Falandysz $(\bowtie) \cdot$ G. Jarzyńska · D. Romińska · K. Damps Institute of Environmental Sciences and Public Health, University of Gdańsk, 18 Sobieskiego Str, 80-952 Gdańsk, Poland

e-mail: jfalandy@chem.univ.gda.pl

I. C. Nnorom

Environmental Chemistry Unit, Department of Industrial Chemistry, Abia State University, Uturu, Abia State, Nigeria hence impose a high risk to human health (JECFA 2010; USEPA 1987). Mushrooms are a highly biodiverse group of organisms that belong to the kingdom of fungi, and many of them are know as effective accumulators of trace elements (Brzostowski et al. 2011; Falandysz 2008 and 2012; Ǩanda and Kučera 2004). Mercury is toxic chemical element that is accumulated in mushrooms to great concentration and methylmercury seems even better accumulated that other chemical form of this metal (Alonso et al. 2000; Falandysz et al. 2002a, b; 2003; 2007a, b; 2012a, b; Stijve and Roshhnik 1974).

The puffballs (Lycoperdales) comprises of three groups, the Calvatia (Giant Puffballs), the Lycoperdon (Common Puffballs), and the Bovista (Tumbling Puffballs). Puffball Lycoperdon perlatum is also known as the Common Puffball, Warted Puffball, Gem-studded Puffball or Devil's Snuff-box. It is a species of puffball mushroom in the Agaricaceae family. The Common Puffballs-the young specimens with white flesh-has long been considered edible and is a culinary favourite in some countries, while the brownish or darker ones are inedible but not poisonous. It is reported to have higher protein content than many other fungi. Mercury contaminations of wild edible mushrooms could pose toxicological risk to consumers because of the toxic nature of $\mathrm{Hg}$ species (JECFA 2010).

Total mercury content of mushrooms could be species dependent and varies amongst their ecological groups (saprophytic, symbiotic etc.), and this is what makes data interpretation difficult for different species and areas (Alonso et al. 2000).

The aim of this study was to investigate the contamination with $\mathrm{Hg}$ of topsoil and L. perlatum collected from ten background and spatially distant sites at the northern part of Poland and to estimate possible $\mathrm{Hg}$ intake by consumers. The bioconcentration factor $(\mathrm{BCF})$ values were calculated to estimate the potential of this species to accumulate $\mathrm{Hg}$. 


\section{Materials and Methods}

Fruiting bodies (carpophores) of L. perlatum and beneath surface layer $(0-10 \mathrm{~cm})$ of soils (ca. $100 \mathrm{~g}$ ) were collected. Sampling of $10 \mathrm{~cm}$-depth horizon was aimed at understanding the spatial difference in $\mathrm{Hg}$ distribution in the soil substrate. The samples were collected from ten sites in Poland, i.e.: Krokowa, Lębork, Lipusz, Kartuzy, Miracho-wo and Łapino at the Pomorskie Voivodeshisp (Pomerania); Kiwity at the Warmia Land (Warmia), Piska forests at the Mazury Land (Masuria), Ciechocinek at Kujawy Land (KujawskoPomorskie Viovodeship) and Poniatowa at the Chodelska Dale (Lubelskie Voivodeship) in 2001-2008 (Table 1).

Fruiting bodies after cleanup from the plant material and particles of soil with a plastic knife were initially air-dried at room temperature in a well-ventilated place for two-three days, and then further oven dried at $65^{\circ} \mathrm{C}$ for $48-96 \mathrm{~h}$. The specimens were next crushed and ground in an agate mortar to fine powder. Soil substrate samples, after removal of visible organisms, small stones, sticks and leaves were air dried at room temperature for approximately 4-6 weeks and then sieved through a pore size of $2 \mathrm{~mm}$.

Total Hg content of materials was determined by coldvapor atomic absorption spectroscopy (CV-AAS) after thermal decomposition of sample matrix and further amalgamation and desorption of element from gold wool (Mercury analyzer type MA-2000, Nippon Instruments Corporation, Takatsuki, Japan). Analytical control and quality assurance (AC/QA) were performed through the analysis of certified reference material CS-M-1 (dried fruiting bodies of mushroom Cow Bolete Suillus bovinus) produced by the Institute of Nuclear Chemistry and Technology in Warsaw, Poland. Declared content $\mathrm{Hg}$ in these certified reference material was $0.174 \pm 0.018$, while our measurements showed $0.171 \pm 0.008 \mu \mathrm{g} / \mathrm{g} \mathrm{dw}(\mathrm{n}=3)$. In addition, with every set of 10 mushroom or soil samples examined, one blank sample was included. For mushroom fruiting bodies and soil substrate the limit of detection (LOD) was $0.005 \mu \mathrm{g} \mathrm{Hg} / \mathrm{g} \mathrm{dw}$, and the quantitation limit (LOQ) was $0.003 \mu \mathrm{g} \mathrm{Hg} / \mathrm{g}$ dw (Jarzyńska and Falandysz 2011).

\section{Results and Discussion}

The results of this study showed varying $\mathrm{Hg}$ concentrations in L. perlatum ranging from 0.57 to $4.5 \mu \mathrm{g} / \mathrm{g}$ dw with the mean values for the sites investigated ranging from $0.91 \pm 0.28 \mu \mathrm{g} / \mathrm{g} \mathrm{dw}$ for Ciechocinek to $2.4 \pm 0.4 \mu \mathrm{g} / \mathrm{g}$

Table 1 Mercury in L. perlatum and soils ( $\mu \mathrm{g} / \mathrm{g} \mathrm{dw}$ ) and values of the BCF (arithmetic mean, SD, range and median, respectively)

\begin{tabular}{|c|c|c|c|}
\hline \multirow[t]{2}{*}{ Site and year } & \multicolumn{2}{|l|}{$\mathrm{Hg}$} & \multirow[t]{2}{*}{$\mathrm{BCF}$} \\
\hline & Caprophores & Soils & \\
\hline $\begin{array}{l}\text { Krokowa, Pomerania, } 2003 \\
\qquad \mathrm{n}=15(85)^{\mathrm{a}}\end{array}$ & $\begin{array}{l}2.4 \pm 0.4 \\
(1.5-2.8) 2.5\end{array}$ & $\begin{array}{l}0.057 \pm 0.018 \\
(0.027-0.090) 0.055\end{array}$ & $\begin{array}{l}46 \pm 14 \\
(19-70) 44\end{array}$ \\
\hline $\begin{array}{l}\text { Lębork, Pomerania, } 2007 \\
\mathrm{n}=15 \text { (84) }\end{array}$ & $\begin{array}{l}1.3 \pm 0.4 \\
(0.69-2.2) 1.3\end{array}$ & $\begin{array}{l}0.043 \pm 0.020 \\
(0.025-0.096) 0.039\end{array}$ & $\begin{array}{l}36 \pm 15 \\
(9.8-55) 39\end{array}$ \\
\hline $\begin{array}{l}\text { Lipusz, Pomerania, } 2007 \\
\qquad \mathrm{n}=15 \text { (47) }\end{array}$ & $\begin{array}{l}2.0 \pm 0.4 \\
(1.2-2.8) 2.0\end{array}$ & $\begin{array}{l}0.020 \pm 0.007 \\
(0.012-0.040) 0.018\end{array}$ & $\begin{array}{l}110 \pm 36 \\
(31-160) 120\end{array}$ \\
\hline $\begin{array}{l}\text { Kartuzy, Pomerania, 2007/2008 } \\
\mathrm{n}=13 \text { (75) }\end{array}$ & $\begin{array}{l}1.9 \pm 0.8 \\
(1.3-3.6) 2.6\end{array}$ & $\begin{array}{l}0.047 \pm 0.034 \\
(0.010-0.080) 0.049\end{array}$ & $\begin{array}{l}100 \pm 100 \\
(25-280) 68\end{array}$ \\
\hline $\begin{array}{l}\text { Mirachowo, Pomerania } 2007 \\
\mathrm{n}=8 \text { (16) }\end{array}$ & $\begin{array}{l}1.1 \pm 0.2 \\
(0.92-1.5) 1.1\end{array}$ & $\begin{array}{l}0.046 \pm 0.016 \\
(0.031-0.073) 0.037\end{array}$ & $\begin{array}{l}28 \pm 11 \\
(13-42) 31\end{array}$ \\
\hline $\begin{array}{l}\text { Łapino, Pomerania, 2006/2007 } \\
\qquad \mathrm{n}=13 \text { (105) }\end{array}$ & $\begin{array}{l}2.0 \pm 0.8 \\
(1.3-3.9) 1.7\end{array}$ & $\begin{array}{l}0.025 \pm 0.007 \\
(0.020-0.045) 0.023\end{array}$ & $\begin{array}{l}83 \pm 34 \\
(29-170) 78\end{array}$ \\
\hline $\begin{array}{l}\text { Kiwity, Warmia, } 2003 \\
\qquad \mathrm{n}=13 \text { (53) }\end{array}$ & $\begin{array}{l}2.4 \pm 1.1 \\
(1.1-4.5) 2.0\end{array}$ & $\begin{array}{l}0.049 \pm 0.036 \\
(0.012-0.12) 0.042\end{array}$ & $\begin{array}{l}77 \pm 47 \\
(9.6-140) 83\end{array}$ \\
\hline $\begin{array}{l}\text { Piska forests, Mazury, } 2003 \\
\mathrm{n}=15^{b}\end{array}$ & $\begin{array}{l}1.3 \pm 0.3 \\
(0.70-1.8) 1.4\end{array}$ & $\begin{array}{l}0.023 \pm 0.005 \\
(0.013-0.032) 0.022\end{array}$ & $\begin{array}{l}65 \pm 27 \\
(22-140) 60\end{array}$ \\
\hline $\begin{array}{l}\text { Ciechocinek, Kujawy, } 2004 \\
\mathrm{n}=15 \text { (58) }\end{array}$ & $\begin{array}{l}0.91 \pm 0.28 \\
(0.57-1.4) 0.82\end{array}$ & $\begin{array}{l}0.012 \pm 0.002 \\
(0.0077-0.015) 0.013\end{array}$ & $\begin{array}{l}75 \pm 24 \\
(47-120) 66\end{array}$ \\
\hline $\begin{array}{l}\text { Poniatowa, Chodelska Dale, } 2001 \\
\mathrm{n}=11\end{array}$ & $\begin{array}{l}1.8 \pm 0.5 \\
(1.1-2.9) 1.7\end{array}$ & $\begin{array}{l}0.063 \pm 0.024 \\
(0.029-0.10) 0.066\end{array}$ & $\begin{array}{l}35 \pm 23 \\
(12-90) 30\end{array}$ \\
\hline
\end{tabular}

${ }^{a}$ Number of samples and number of fruiting bodies (in parentheses)

b Number of fruiting bodies 
Table 2 Mercury in Puffball and soils ( $\mu \mathrm{g} / \mathrm{g} \mathrm{dw})$ in Europe and values of the BCF (arithmetic mean, SD, range and median, respectively)

\begin{tabular}{|c|c|c|c|c|}
\hline \multirow[t]{2}{*}{ Site and year } & \multicolumn{3}{|l|}{$\mathrm{Hg}$} & \multirow[t]{2}{*}{ References } \\
\hline & Caprophore & Soils & $\mathrm{BCF}$ & \\
\hline $\begin{array}{l}\text { Sweden, Umeå, } \\
1995 \text { n-6(30) }\end{array}$ & $1.6 \pm 0.7(0.77-2.8)$ & $0.10 \pm 0.13(0.018-0.25)$ & $65 \pm 29(11-110)$ & $\begin{array}{l}\text { Falandysz et al. } \\
\text { (2001) }\end{array}$ \\
\hline $\begin{array}{l}\text { Poland, Rogóźno, } \\
\text { 1984/85 n-1 }\end{array}$ & 1.4 & & & $\begin{array}{l}\text { Lasota and Witusik } \\
\text { (1987) }\end{array}$ \\
\hline $\begin{array}{l}\text { Poland, Łubiana, } \\
\text { Kościerzyna county, } \\
1993 \text { n = 15 }\end{array}$ & $1.1 \pm 0.4(0.48-1.9) 1.1$ & & & $\begin{array}{l}\text { Falandysz et al. } \\
\text { (1996) }\end{array}$ \\
\hline $\begin{array}{c}\text { Poland, Zaborski } \\
\text { Landscape Park, } \\
1997 / 98 \text { n }=16\end{array}$ & $\begin{array}{l}3.7 \pm 1.7(1.5-6.8) \\
3.3\end{array}$ & $\begin{array}{l}0.031 \pm 0.021(0.0091-0.072) \\
0.025\end{array}$ & $\begin{array}{l}160 \pm 120(46-420) \\
120\end{array}$ & $\begin{array}{l}\text { Falandysz et al. } \\
\text { (2002a) }\end{array}$ \\
\hline $\begin{array}{l}\text { Poland, Borecka Forest, } \\
1998 \mathrm{n}=16(146)^{\mathrm{a}}\end{array}$ & $3.4 \pm 1.3(1.3-6.1) 3.2$ & $\begin{array}{l}0.020 \pm 0.019(0.009-0.040) \\
0.018\end{array}$ & $\begin{array}{l}200 \pm 91 \\
190\end{array}$ & $\begin{array}{l}\text { Falandysz et al. } \\
\text { (2002b) }\end{array}$ \\
\hline $\begin{array}{l}\text { Poland, Łukta and Morag, } \\
1997 / 98 \mathrm{n}=16(168)^{\mathrm{a}}\end{array}$ & $2.8 \pm 0.5(1.3-3.1) 2.2$ & $0.054 \pm 0.12(0.012-0.41) 0.026$ & $89 \pm 48(6.6-210) 78$ & $\begin{array}{l}\text { Falandysz et al. } \\
\text { (2003) }\end{array}$ \\
\hline $\begin{array}{l}\text { Poland, 2001-2007 } \\
\mathrm{n}=133(549)^{\mathrm{a}}\end{array}$ & $\begin{array}{l}0.91 \pm 0.28-2.4 \pm 1.1 \\
(0.57-4.5) ; 0.82-2.6\end{array}$ & $\begin{array}{l}0.012 \pm 0.002-0.063 \pm 0.024 \\
(0.0077-0.12)\end{array}$ & $\begin{array}{l}28 \pm 11-110 \pm 36 \\
(9.6-280)\end{array}$ & b \\
\hline Germany $n=2$ & $3.3(1.5-5.1)$ & & & Seeger (1976) \\
\hline Slovakia & $2.0 \pm 0.6(0.3-3.2)$ & & & Svoboda et al. (2006) \\
\hline $\begin{array}{l}\text { Bohemia, Precambrian } \\
\text { shales }\end{array}$ & $3.5 \pm 0.1$ & & & $\begin{array}{l}\text { Řanda and Kučera } \\
\text { (2004) }\end{array}$ \\
\hline $\begin{array}{l}\text { Bohemia, vicinity of multi- } \\
\text { metal smelting plant }\end{array}$ & $4.0 \pm 0.1$ & & & \\
\hline $\begin{array}{l}\text { Switzerland, Lausanne, } \\
\text { contaminated site }\end{array}$ & $16(6.6-22) 8.6$ & & & Quinche (1979) \\
\hline $\begin{array}{l}\text { Switzerland, Lausanne, } \\
\text { background site }\end{array}$ & $2.6(2.3-5.8) 3.8$ & & & Quinche (1979) \\
\hline Switzerland & 0.58 [MeHg: 0.012] & & 6.3 [MeHg: 12] & Reider et al. (2011) \\
\hline Slovenia $\mathrm{n}=2$ & $2.2(2.1-2.3)$ & & & Byrne et al. (1979) \\
\hline $\begin{array}{l}\text { Slovenja, Idrija, } \mathrm{Hg} \text { melting } \\
\text { site } \mathrm{n}=1\end{array}$ & 41 & & & Stegnar et al. (1973) \\
\hline $\begin{array}{l}\text { Slovenja, } 5 \mathrm{~km} \text { from Idrija } \\
\mathrm{Hg} \text { melting site } \mathrm{n}=1\end{array}$ & $32[\mathrm{MeHg} 3.5]$ & & & Stegnar et al. (1973) \\
\hline Slovenja, Podljubelj $n=6$ & 27 (20-34) [MeHg: 0.35] & $11(7.1-19)$ & & Stegnar et al. (1973) \\
\hline Slovenja, Podljubelj $n=7$ & 25 (17-28) [MeHg: 0.35] & & & Stegnar et al. (1973) \\
\hline $\begin{array}{l}\text { Slovenja, background area } \\
\mathrm{n}=3\end{array}$ & $8.4(5.3-14)$ [MeHg: 0.36] & $0.55(0.53-0.58) \mathrm{n}=2$ & & Stegnar et al. (1973) \\
\hline Italy, Siena $\mathrm{n}=1$ & 2.8 & 0.31 & 9.0 & $\begin{array}{l}\text { Bargagli and Baldi } \\
\quad(1984)\end{array}$ \\
\hline Italy, Regino di Emilia & $1.9(1.2-2.6)$ & & & Cocchi et al. (2006) \\
\hline
\end{tabular}

${ }^{a}$ Number of samples and number of fruiting bodies (in parentheses)

b Present study

dw for the sites Krokowa and Kiwity. The range of the median values according to site is $0.82-2.5 \mu \mathrm{g} / \mathrm{g} \mathrm{dw}$ for Ciechocinek and Krokowa, respectively (Table 1).

The results of this study are comparable to earlier reports for $\mathrm{Hg}$ in L. perlatum for specimens from background areas of Sweden, Poland, Slovakia, Switzerland, and Italy (Table 2).

Total $\mathrm{Hg}$ content of topsoil depending on the site, revealed low contamination with this element and mean concentrations varied between $0.012 \pm 0.002$ and $0.063 \pm$ 0.024 (overall range $0.0077-0.12$ ) $\mu \mathrm{g} / \mathrm{g}$ dry weight in soils (Table 1). The greatest $\mathrm{Hg}$ in soil at $0.12 \mu \mathrm{g} / \mathrm{g}$ was observed in a sample from Kiwity, site. None of the surveyed sites was recognized as being under the influence of any point $\mathrm{Hg}$ pollution source. These soils $\mathrm{Hg}$ data of the present study imply background levels since the range of concentration values reported for forest soils in a boarder study conducted in Poland revealed values usually well 
below $0.5 \mu \mathrm{g} / \mathrm{g} \mathrm{dw}$ (Drewnowska et al. 2012; Falandysz et al. 1996, 2002a, b; 2003; 2007a, b; 2012a, b). Higher soil $\mathrm{Hg}$ concentrations of $0.53-0.58$, and $7.1-19 \mu \mathrm{g} / \mathrm{g}$ were reported for some soils from Slovenia while $0.31 \mu \mathrm{g} / \mathrm{g}$ in soils from Italy (Table 2).

Based on calculated values of BCF L. perlatum could be classified as a good accumulator of $\mathrm{Hg}$ as all samples showed very high $\mathrm{BCF}$ values $(\mathrm{BCF} \geq 10$; range 9.6-280) (Table 1). The highest BCF of this study (280), though higher than the maximum BCF values reported by some earlier studies (maximum up to 110 or 210), it is however lower than the maximum BCF of 420 reported for Zaborski Landscape Park (Table 2).

To assess the health risk to consumers due to $\mathrm{Hg}$ contained in the $L$. perlatum the mean, median and range concentrations in (Table 1) and reference dose (RfD: $0.0003 \mathrm{mg} / \mathrm{kg}$ bw daily) were used in estimating the Provisional Tolerable Weekly Intake (PTWI: $0.004 \mathrm{mg} / \mathrm{kg} \mathrm{bw}$ ) values (JECFA 2010; USEPA 1987). A meal consisting of $300 \mathrm{~g}$ of fresh puffball would expose a consumer to $\mathrm{Hg}$ dose ranging from $27 \mu \mathrm{g} \mathrm{Hg}$ at the Ciechocinek site to $72 \mu \mathrm{g} \mathrm{Hg}$ at the Krokowa and Kiwity, considering the mean concentration of $\mathrm{Hg}$ contents of Puffballs collected from these sites. And these values are $130 \%$ and $340 \%$ of the daily $\mathrm{Hg}$ reference doses respectively. The amount of fresh caps needed so as not to exceed this $\mathrm{Hg}$ limit for $70 \mathrm{~kg}$ body weight individual would be $0.23 \mathrm{~kg}$ at $\mathrm{Ci}-$ echocinek and $0.087 \mathrm{~kg}$ at both the Krokowa and the Kiwity sites. Considering the established PTWI value and the mean mushroom $\mathrm{Hg}$ contents for the various sites investigated, consumption of a meal made of $300 \mathrm{~g}$ of $L$. perlatum for a week could provide depending on the site from $191 \mu \mathrm{g} \mathrm{Hg}$ at Ciechocinek to $504 \mu \mathrm{g} \mathrm{Hg}$ at both the Krokowa and Kiwity, respectively, and this would comprise from $1,900 \%$ to $5,300 \%$ of PTWI. This shows that the consumption of this mushroom could pose health risks to consumers.

Acknowledgments Technical support by Anna Dryżałowska, Dorota Górska, Aleksandra Jabłońska, Edyta Kułdo, Damroka Reglińska and Justyna Wenta is acknowledged. This study was supported by the Ministry of Science and Higher Education under project DS-8130-4-0092-1.

Open Access This article is distributed under the terms of the Creative Commons Attribution License which permits any use, distribution, and reproduction in any medium, provided the original author(s) and the source are credited.

\section{References}

Alonso J, Salgado MJ, Garcia MA, Melgar MJ (2000) Accumulation of mercury in edible macrofungi, influence of some factors. Arch Environ Contam Toxicol 38:158-162
Bargagli R, Baldi F (1984) Mercury and methyl mercury in higher fungi and their relation with substrata in a cinnabar mining area. Chemosphere 13:1059-1071

Brzostowski A, Falandysz J, Jarzyńska G, Zhang D (2011) Bioconcentration potential of metallic elements by poison pax (Paxillus involutus) mushroom. J Environ Sci Health A 46:378-393

Byrne AR, Dermelj M, Vakselj T (1979) Silver accumulation by fungi. Chemosphere 10:815-821

Cocchi L, Vescovi L, Petrini LE, Petrini O (2006) Heavy metals in edible mushrooms in Italy. Food Chem 98:277-284

Drewnowska M, Jarzyńska G, Kojta AK, Falandysz J (2012) Mercury in European Blusher, Amanita rubescens, mushroom and soil. Bioconcentration potential and intake assessment. J Environ Sci Health B 47:466-474

Falandysz J (2008) Selenium in edible mushrooms. J Environ Sci Health C 26:256-299

Falandysz J (2012) Comments on "Determination of mercury, cadmium, lead, zinc, selenium and iron by ICP-OES in mushroom samples from around thermal power plant in Muğla, Turkey". doi:10.1007/s00128-011-0357-1. Bull Environ Contam Toxicol 88:651-653. doi:10.1007/s00128-012-0566-2

Falandysz J, Marcinowicz A, Chwir A (1996) Rtęć w jadalnych grzybach z terenu lasów kościerskich i Mierzei Wiślanej. Roczn Państw Zakł Hig 47:206-210

Falandysz J, Gucia M, Frankowska A, Kawano M, Skwarzec B (2001) Total mercury in wild mushrooms and underlying soil substrate from the city of Umeå and its surroundings, Sweden. Bull Environ Contam Toxicol 67:763-770

Falandysz J, Lipka K, Gucia M, Kawano M, Strumnik K, Kannan K (2002a) Accumulation factors of mercury in mushrooms from Zaborski Landscape Park, Poland. Environ Intern 28:421-427

Falandysz J, Gucia M, Skwarzec B, Frankowska A, Klawikowska K (2002b) Total mercury in mushrooms and underlying soil from the Borecka Forest, Northeastern Poland. Arch Environ Contam Toxicol 42:145-154

Falandysz J, Kawano M, Świeczkowski A, Brzostowski A, Dadej M (2003) Total mercury in wild-grown higher mushrooms and underlying soil from Wdzydze Landscape Park, Northern Poland. Food Chem 81:21-26

Falandysz J, Gucia M, Mazur A (2007a) Content and bioconcentration factors of mercury by Parasol Mushroom Macrolepiota procera. J Environ Sci Health B 42:735-740

Falandysz J, Frankowska A, Mazur A (2007b) Mercury and its bioconcentration factors in King Bolete (Boletus edulis). Bull Fr J Environ Sci Health A 42:2089-2095

Falandysz J, Widzicka E, Kojta AK, Jarzyńska G, Drewnowska M, Danisiewicz-Czupryńska D, Dryżałowska A, Lenz E, Nnorom IC (2012a) Mercury in Common Chanterelles mushrooms: Cantharellus spp. update. Food Chem 133:842-850

Falandysz J, Kojta AK, Jarzyńska G, Drewnowska A, Dryżałowska A, Wydmańska D, Kowalewska I, Wacko A, Szlosowska M, Kannan K, Szefer P (2012b) Mercury in Bay Bolete Xerocomus badius: bioconcentration by fungus and assessment of element intake by humans eating fruiting bodies. Food Addit Contam A 29:951-961

Jarzyńska G, Falandysz J (2011) The determination of mercury in mushrooms by CV-AAS and ICP-AES techniques. J Environ Sci Health A 46:569-573

JECFA (2010) Joint FAO/WHO Expert committee on food additives. Seventy-second meeting. Rome, 16-25 February 2010. Summary and conclusions. JECFA/72/SC. Food and Agriculture Organization of the United Nations World Health Organization. Issued 16th March 2010

Lasota W, Witusik M (1987) Zawartość rtęci w grzybach dziko rosnących i podłożu. Problemy Higieny 1:125-134 
Quinche JP (1979) Tenur en quelques èlèmentes traces du Lycoperdon perlatum. Bull Romand de Mycol 10:13-14

Řanda Z, Kučera J (2004) Trace elements in higher fungi (mushrooms) determined by activation analysis. J Radioanal Nucl Chem 259:99-107

Reider SR, Brunner I, Horvat M, Jacobs A, Frey B (2011) Accumulation of mercury and methylmercury by mushrooms and earthworms from forest soils. Environ Pollut 159:2861-2869

Seeger R (1976) Quecksilber gehalt der Pilze. Z Lebensm Unters Forsch 160:303-312

Stegnar P, Kosta L, Byrne AR, Ravnik V (1973) The accumulation of mercury by, and the occurrence of methyl mercury in, some fungi. Chemosphere 2:57-63
Stijve T, Roschnik R (1974) Mercury and methyl mercury content of different species of fungi. Travaux de chimie alimentaire et d'hygiène 65:209-220

Svoboda L, Havličková B, Kalač P (2006) Contents of cadmium, mercury and lead in edible mushrooms growing in a historical silver-mining area. Food Chem 96:580-585

USEPA (1987) United States Environmental Protection Agency peer review workshop on mercury issues. Summary report. Environmental Criteria and Assessment Office, U.S. EPA, Cincinnati, $\mathrm{OH}$, October 26-27 